\title{
Akım Geri Beslemeli İşlemsel Kuvvetlendirici Kullanılarak Topraklanmış Endüktans Simülatör Topolojileri
}

\section{Current Feedback Operational Amplifier Based Grounded Inductance Simulator Topologies}

\author{
Muhammed Emin BASSAK* \\ Yıldız Teknik Üniversitesi, Gemi İnşaatı ve Denizcilik Fakültesi, Gemi İņaatı ve Gemi Makineleri Mühendisliği, 34349, İstanbul \\ • Geliş tarihi / Received: 22.11 .2017 • Düzeltilerek geliş tarihi / Received in revised form: 17.05.2018 • Kabul tarihi / Accepted: 09.06 .2018
}

\begin{abstract}
Öz
Endüktans simülatörleri; faz kaydırıcılar, aktif filtre devreleri, osilatörler ve parazitlikleri önleyici devre tasarımlarında kullanılmaktadırlar. Akım geri beslemeli işlemsel kuvvetlendirici (CFOA) elemanı ile birlikte pasif elemanlar kullanılarak topraklanmış üç adet endüktans simülatörü tasarlanmıştır. Bu çalışmanın amacı düşük frekanslarda çalışabilen en az sayıda aktif ve pasif eleman kullanarak yeni endüktans simülatörleri elde etmektir. Önerilen endüktans simülatörlerinden birincisi iki seri direnç ve endüktanstan $\left(R_{1}+R_{2}+L\right)$, ikincisi seri direnç ve endüktanstan (-R-L); üçüncüsü ise iki direncinin eşitliği durumunda $\left(\mathrm{R}_{2}=\mathrm{R}_{3}\right)$ kayıpsız endüktanstan (-L)'den oluşmaktadır. Önerilen simülatörlerin başarımı AD844 CFOA LTSpice modeliyle RLC süzgeç benzetimi yapılarak gösterilmiştir. Sonuçların teorik analiz ile uyum içinde olduğu görülmüştür. LTSpice programı ile yapılan simülasyonlar ile teorik sonuçların bağdaştı̆ı görülmüş̧ür.
\end{abstract}

Anahtar kelimeler: Akım geri beslemeli işlemsel kuvvetlendirici, Endüktans simülatörü, Süzgeç

\begin{abstract}
Inductance Simulators can be used to implement phase shifting circuits, active filters, oscillators, cancellation of parasitic elements. In this work, three inductor simulators employing only a single active circuit current feedback operational amplifier, and three passive components have been proposed. The aim of this work, is to show new inductance simulators working the low frequencies using minimum number of active and passive elements. The first topology designed for series lossy inductance consists of two resistors and inductors $\left(R_{1}+R_{2}+L\right)$, the second topology consists of $(-R-L)$ and the third topology is lossless negative inductance if the two resistors are equal $\left(R_{2}=R_{3}\right)$. To demonstrate the performance of the proposed simulated inductors, passive RLC filter has been used with AD844 CFOA Spice model. The simulations performed with the LTSpice program agree with the theoretical analysis.
\end{abstract}

Keywords: Current Feedback Operational Amplifier, Inductor simulator, Filter

* Muhammed Emin BAŞAK; mebasak@yildiz.edu.tr; Tel: (212) 38328 50; orcid.org/0000-0001-5520-8579 


\section{Giriş}

Pasif endüktanslar çok fazla alan kapladıkları, ideal duruma göre farklı karakteristik gösterdikleri ve düşük kalite faktörüne sahip oldukları için pek tercih edilmezler. Pasif endüktansların yerine daha az yer kaplayan, yüksek kalite faktörüne sahip endüktans simülatörleri tercih edilirler. Endüktans simülatörleri; faz kaydırıcılar, aktif filtre devreleri, osilatörler ve parazitlik önleyici devrelerde yaygın bir şekilde kullanılmaktadırlar.

Yüksek hacimli ve pahalı pasif endüktansların yerine literatürde çok sayı ve çeşitte aktif elemanlardan elde edilmiş endüktans simülatörleri mevcuttur. Farklı aktif elemanlardan elde edilen endüktans simülatörleri için işlemsel geçiş resistans1 kuvvetlendiricisi (OTRA) (Pramanik, 2015; Nagar ve Paul, 2016); ikinci derecen akım taşıyıcı devreleri (CCII) (Paul ve Patranabis, 1981; Ferri ve Guerrini, 2003), dört uçlu yüzen nullor (FTFN) (Kumar ve Senani, 2010); gerilim fark1 alan tampon (buffer) kuvvetlendirici (VDBA) (Yeşil vd, 2014; Yesil ve Kacar, 2016); gerilim farkı alan akım taşıyıcı (DVCC) (Abaci ve Yuce, 2017) ve akım geri beslemeli işlemsel kuvvetlendirici (CFOA) (Kaçar ve Kuntman, 2011; Abuelma'atti, 2012; Başak ve Kaçar, 2018) örnek olarak verilebilir.

Özellikle düşük frekanslı uygulamalar için kullanılacak yüksek değerli endüktansların yonga (chip) teknolojisi ile üretilmeleri mümkün değildir. Dolayısıyla birçok farklı aktif elemanla tasarlanmış endüktans simülatörü literatürde görülebilir. Ancak ticari olmayıp, piyasada bulunmayan diferansiyel gerilimli akım taşıyıcı (DVCC) (Abaci ve Yuce, 2017), diferansiyel fark akım taşıyıcı (DDCC) (Ibrahim vd., 2011, 2012) veya gerilim farkı akım taşıyıcı (VDCC) (Kaçar vd., 2014) gibi aktif elemanlarla elde edilen endüktans simülatörlerinin gerçeklenmesi için aktif elemanların üretilmeleri gerekmektedir. Birden fazla aktif elemanla elde edilen simülatörlerin de gerçeklemesi daha zordur. $\mathrm{Bu}$ çalışmada bir adet CFOA ve üç veya dört pasif eleman (iki direnç ve bir kondansatör veya üç direnç ve bir kondansatör) kullanılarak ticari olarak bulunabilen AD844 ile elde edilen endüktans simülatörleri önerilmiştir. Önerilen endüktans simülatörü ile önceden tasarlanmış modellerin karşılaştırılması Tablo 1'de yapılmıştır.

Yüksek yetişme hızına (slew rate) sahip olması ve sabit kazanç-bant genişliği çarpımı kısıtlaması olmamasına rağmen CFOA, geleneksel işlemsel kuvvetlendiriciler (OA) kadar temel elektronik kaynaklarında yer bulamamaktadır (Sedra ve Smith, 2015). Elbette ki bu durum akım geri beslemeli işlemsel kuvvetlendiricilerin ileride de kullanılmayacağını göstermez.

$\mathrm{Bu}$ çalışmada üç farklı, topraklanmış endüktans simülatörü önerilmiştir. Önerilen simülatörler akım geri beslemeli işlemsel kuvvetlendirici kullanılarak gerçeklenmişlerdir. Akım geri beslemeli işlemsel kuvvetlendirici olarak piyasada AD844 olarak bilinen entegre kullanilabilir. Böylelikle tasarlanan simülatörler rahatlıkla gerçeklenebilir. Elde edilen endüktans simülatörlerinden birincisi seri olarak iki direnç ve endüktans1 içerir. İkincisi seri (-R-L)'den oluşmakta, üçüncüsü ise iki direncin eşitliği durumunda $\left(\mathrm{R}_{2}=\mathrm{R}_{3}\right)$ negatif topraklı endüktans (L) elde edilmesini sağlamaktadır.

Tablo 1. Önerilen topraklanmış endüktans simülatörü ile literatürdeki modellerin karşılaştırılması

\begin{tabular}{|l|l|l|l|l|l|}
\hline Kaynak & Aktif eleman & $\begin{array}{l}\text { Aktif eleman } \\
\text { sayısı }\end{array}$ & $\begin{array}{l}\text { Direnç } \\
\text { sayısı }\end{array}$ & $\begin{array}{l}\text { Kapasitör } \\
\text { sayısı }\end{array}$ & $\begin{array}{l}\text { Ticari } \\
\text { bulunabilirlik }\end{array}$ \\
\hline Nagar ve Paul, 2016 & OTRA & 1 & 3 & 1 (yüzen) & Evet \\
\hline Pramanik, 2015 & OTRA & 2 & 5 & 1 (toprakl1) & Evet \\
\hline Paul ve Patranabis, 1981 & CCII & 1 & 4 & 1 (yüzen) & - \\
\hline Kumar ve Senani, 2010 & PFTFN & 1 & 4 & 1 (yüzen) & Hayır \\
\hline Yeşil ve Kaçar, 2016 & VDBA & 1 & 2 & 1 (toprakl1) & Evet \\
\hline Yeşil ve Diğ., 2014 & VDBA & 1 & 1 & 1 (yüzen) & Evet \\
\hline Abaci ve Yüce, 2017 & DVCC & 1 & 2 & 1 (toprakl1) & Hayır \\
\hline İbrahim vd., 2011 & MDO-DDCC & 1 & 2 & 1 (topraklı) & Hayır \\
\hline İbrahim vd., 2012 & MDO-DDCC & 1 & 2 & 1 (toprakl1) & Hayır \\
\hline Abuelma'atti, 2012 & CFOA & 1 & 3 & 1 & Evet \\
\hline Kaçar ve Kuntman, 2011 & CFOA & 1 & 2 & 1 (yüzen) & Evet \\
\hline Başak, Kaçar, 2018 & CFOA & 1 & 2 & 1 (yüzen) & Evet \\
\hline Önerilen & CFOA & $\mathbf{1}$ & $\mathbf{2}$ & $\mathbf{1}$ (yüzen) & Evet \\
\hline
\end{tabular}


Elde edilen endüktans ile bir filtre devresi tasarlanmış ve yüksek geçiren, band geçiren ve alçak geçiren sonuçları elde edilmiştir. Önerilen endüktans simülatörünün piyasada bulunabilen aktif elemanla (AD844) tasarlanabilmesi dışında, yüksek değerli olması ve düşük frekanslarda çalışabilmesi amaçlanmıştır. Bu çalışmada en az sayıda aktif ve pasif eleman kullanarak düşük frekansta çalışabilen endüktans simülatörü tasarlamak hedeflenmiştir.

Çalışmanın ikinci bölümünde CFOA'nın karakteristik denklemi ile birlikte önerilen endüktans simülatörleri verilmiştir. Üçüncü bölümde önerilen endüktans simülatörü ile süzgeç tasarımı yapılarak devrenin başarımı gözlenmiştir. Çok düşük frekanslarda da çalışabildiği LTSpice simülasyonlarıyla gösterilen simülatörün analog devre uygulamalarında faydalı olacağı düşünülmektedir.

\section{2. Önerilen Endüktans Simülatörleri}

Önerilen endüktans simülatörleri için CFOA kullanılmıştır. CFOA'ya ait eşdeğer devre Şekil 1'de karakteristik matrisi ise Denklem 1'de verilmiştir.

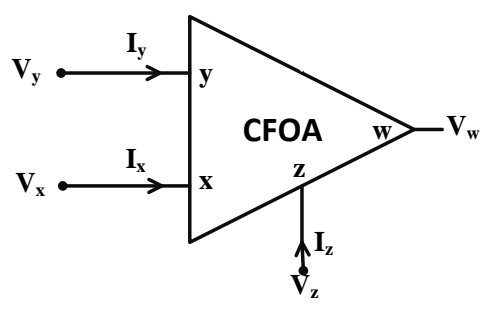

Şekil 1. CFOA elemanının devre sembolü

$$
\left[\begin{array}{l}
I_{y} \\
I_{z} \\
V_{x} \\
V_{w}
\end{array}\right]=\left[\begin{array}{lll}
0 & 0 & 0 \\
\alpha & 0 & 0 \\
0 & \beta & 0 \\
0 & 0 & \gamma
\end{array}\right]\left[\begin{array}{l}
I_{x} \\
V_{y} \\
V_{z}
\end{array}\right]
$$

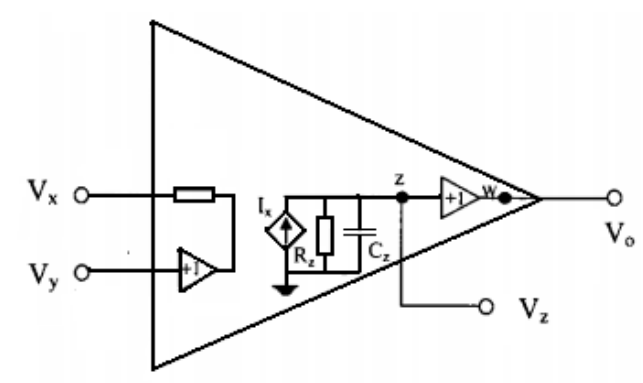

Şekil 2. CFOA eşdeğer devresi
CFOA devresi için Şekil 1'deki gibi standart notasyon kullanılirsa $I_{\mathrm{y}}=0, I_{\mathrm{z}}=I_{\mathrm{x}}, V_{\mathrm{x}}=\mathrm{V}_{\mathrm{y}}$ ve $\mathrm{V}_{\mathrm{w}}$ $=\mathrm{V}_{\mathrm{z}}$ olarak alınabilir. İdeal olmayan CFOA için ise s-domaininde aşağıdaki eşitlikler gösterilebilir.

$$
\begin{aligned}
& \mathrm{I}_{\mathrm{y}}=\left(\mathrm{sC}_{\mathrm{y}}+1 / \mathrm{R}_{y}\right) \mathrm{V}_{\mathrm{y}} \\
& \mathrm{I}_{\mathrm{z}}=\alpha \mathrm{I}_{\mathrm{x}}+\left(\mathrm{sC}_{\mathrm{z}}+1 / \mathrm{R}_{\mathrm{z}}\right) \mathrm{V}_{\mathrm{z}} \\
& \mathrm{V}_{\mathrm{x}}=\beta \mathrm{V}_{\mathrm{y}}+R_{\mathrm{x}} \mathrm{I}_{\mathrm{x}} \\
& \mathrm{V}_{\mathrm{w}}=\gamma \mathrm{V}_{\mathrm{z}}+\mathrm{R}_{\mathrm{w}} \mathrm{I}_{\mathrm{w}}
\end{aligned}
$$

Burada $R_{x}, R_{y}, R_{z}$ ve $R_{w}$ alt indislerde gösterilen ilgili porttaki parazitik dirençleri; $\mathrm{C}_{\mathrm{y}}$ ve $\mathrm{C}_{\mathrm{z}}$ ise alt indislerde gösterilen portlara ait parazitik kapasitansları ifade etmektedir. Eşitlik 2'den Eşitlik 4'e kadar olan denklemler pozitif tipli ikinci jenerasyon akım taşıyıcılar (CCII+) ile aynıdır. Dolayısıyla CFOA için tampon (buffer) eklenmiş akım taşıyıcıdır denilebilir. CFOA'daki akım geri besleme (CF) kısmı, CCII'daki Y terminalinin topraklanması ile elde edilebilir. $X$ ve $\mathrm{W}$ terminallerindeki ideal durumda sifir olarak alınan $R_{x}$ ve $R_{w}$ parazitik empedansların seri olduğu Eşitlik 4 ve Eşitlik 5'de görülebilir. Diğer yandan $R_{z}=1 / G_{z}$ ve $R_{y}=1 / G_{y}$ parazitik dirençleri $1 /\left(\mathrm{sC}_{\mathrm{z}}\right)$ ve $1 /\left(\mathrm{sC}_{\mathrm{y}}\right)$ ile paraleldir ve ideal olarak da sonsuzdur. $\mathrm{Bu}$ parazitik elemanlar endüktans simülatörüne fazladan terimler getirmektedirler ve simülatör devrelerinde frekans performanslarını arttırmak için indirgeme yöntemleri kullanılabilir (Kaçar ve Kuntman, 2011).

Şekil 3 (a), (b) ve (c)'de önerilen endüktans simülatörleri verilmiştir. Önerilen simülatörler için ideal durumlar $\left(\mathrm{I}_{\mathrm{y}}=0, \mathrm{I}_{\mathrm{z}}=\mathrm{I}_{\mathrm{x}}, \mathrm{V}_{\mathrm{x}}=\mathrm{V}_{\mathrm{y}}\right.$ ve $\mathrm{V}_{\mathrm{w}}=$ $\left.\mathrm{V}_{\mathrm{z}}\right)$ ve ideal olmayan durumlar için $\left(\mathrm{I}_{\mathrm{y}}=0, \mathrm{I}_{\mathrm{z}}=\right.$ $\alpha \mathrm{I}_{\mathrm{x}}, \mathrm{V}_{\mathrm{x}}=\beta \mathrm{V}_{\mathrm{y}}$ ve $\mathrm{V}_{\mathrm{w}}=\gamma \mathrm{V}_{\mathrm{z}}$ ) giriş empedansları Tablo 2'de verilmiştir. Tablo 2'ye göre Şekil 3(a)'da önerilen devre seri direnç $\left(\mathrm{R}_{2}\right)$ ve seri eşdeğer kayıplı endüktanstan $\left(\mathrm{L}_{\mathrm{eq}}=\mathrm{R}_{1} \mathrm{R}_{2} \mathrm{Cs}\right)$ oluşmaktadır. Şekil 3(b)'deki endüktans simülatörü seri negatif direnç $\left(-R_{2}\right)$ ve dirence seri negatif kayipl1 endüktanstan $\left(\mathrm{L}_{\mathrm{eq}}=-\mathrm{R}_{1} \mathrm{R}_{2} \mathrm{Cs}\right)$ oluşmaktadır. Şekil 3(c)'de önerilen endüktans simülatörü ise $R_{2}$ ve $R_{3}$ dirençlerinin eşit olmaları durumunda negatif topraklı kayıpsız endüktans $\left(\mathrm{R}_{2}=\mathrm{R}_{3} \quad\right.$ durumunda $\left.\quad \mathrm{L}_{\mathrm{eq}}=-\mathrm{R}_{1} \mathrm{R}_{2} \mathrm{Cs}\right)$ elde edilmektedir. Şekil 3(c)'deki endüktans simülatörünün, ideal endüktans ile giriş empedanslarının frekansla değişimi için karşılaş̧ırılması Şekil 4'de verilmiştir. Şekilden de görüldüğü gibi önerilen endüktans simülatörü 1 $\mathrm{Hz}$ ile $50 \mathrm{kHz}$ arasında ideal endüktans gibi davranmaktadir. 
Tablo 2. Önerilen simülatörler için ideal ve ideal olmayan eşdeğer empedans denklemleri

\begin{tabular}{|l|l|l|}
\hline Devre & İdeal Olmayan Empedans $\left(\mathbf{Z}_{\mathbf{e q}}\right)$ & İdeal Empedans $\left(\mathbf{Z}_{\mathbf{e q}}\right)$ \\
\hline Şekil 3 (a) & $\frac{R_{2}}{\beta \gamma+C \mathrm{R}_{2} s(1-\beta \gamma)}+\frac{C \mathrm{R}_{1} \mathrm{R}_{2} S}{\beta \gamma+C \mathrm{R}_{2} s(1-\beta \gamma)}$ & $\mathrm{R}_{2}+C \mathrm{R}_{1} \mathrm{R}_{2} S$ \\
\hline Şekil 3 (b) & $-\frac{\alpha \beta \gamma}{\mathrm{R}_{2}}-\frac{C \mathrm{R}_{1} \mathrm{R}_{2} S}{\alpha \beta \gamma}$ & $-\mathrm{R}_{2}-C \mathrm{R}_{1} \mathrm{R}_{2} S$ \\
\hline Şekil 3 (c) & Ĕger $\mathrm{R}_{2}=\mathrm{R}_{3}$ olursa $\mathrm{Z}_{\text {in }}=-\mathrm{sCR}_{1} \mathrm{R}_{2}$ & $\mathrm{R}_{2}=\mathrm{R}_{3}$ için $\mathrm{Z}_{\text {in }}=-\mathrm{sCR}_{1} \mathrm{R}_{2}$ \\
\hline
\end{tabular}

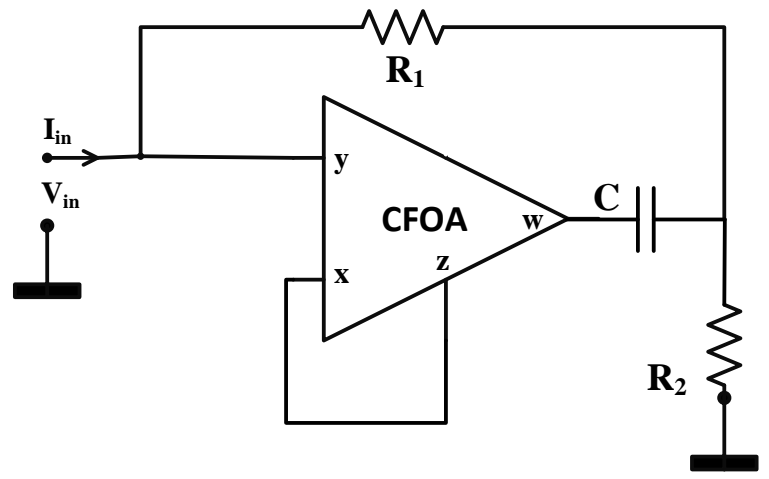

(a)

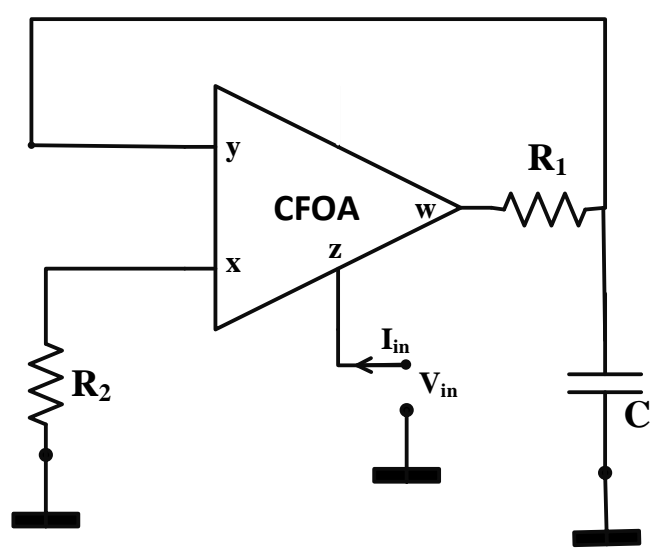

(b)

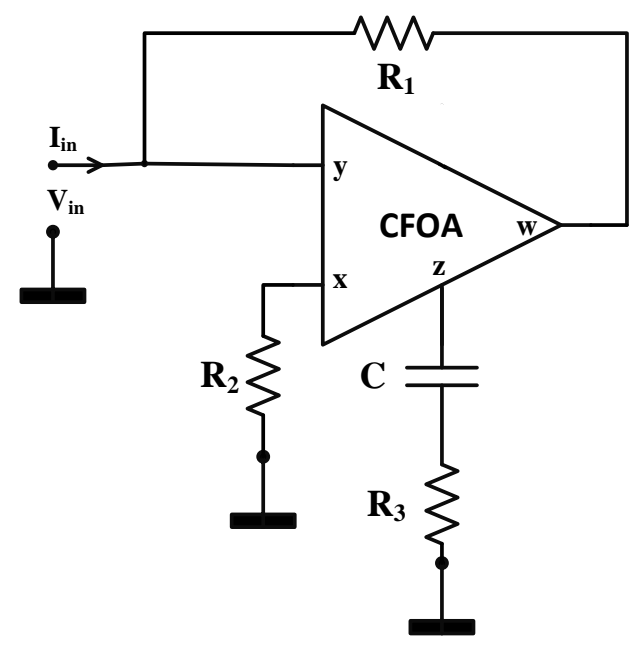

(c)
Şekil 3. Önerilen CFOA endüktans simülatörleri

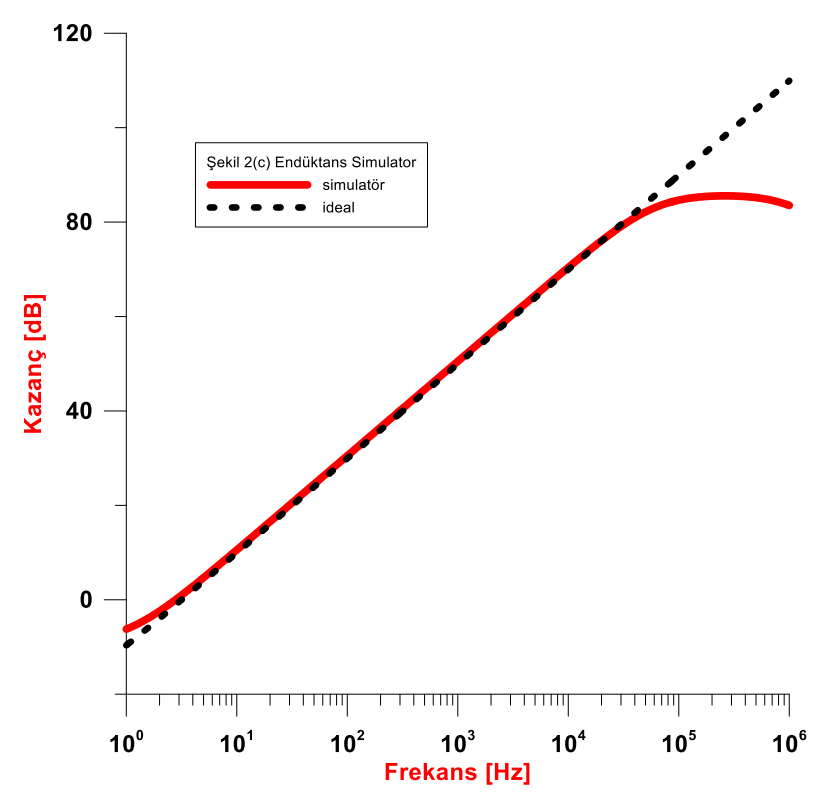

Şekil 4. Önerilen Endüktans Simülatörü (Şekil 3 (c)) için Giriş Empedansının frekansla değişimi

\section{Süzgeç Tasarımı}

Önerilen endüktans simülatörünün başarımını göstermek için süzgeç devresi tasarlanmıştır. Pasif $\mathrm{R}_{\mathrm{L}}$ ve $\mathrm{C}_{\mathrm{L}}$ elemanları ile birlikte Şekil 3(c)'deki endüktans simülatörü kullanılarak oluşturulan süzgeç Şekil 5'de gösterilmiştir. Tasarlanan süzgeç devresinin benzetimi LTSpice programı ile AD844 CFOA kullanılarak yapılmıştır. Besleme kaynakları olarak $\mathrm{V}_{\mathrm{DD}}=12 \mathrm{~V}$ ve $\mathrm{V}_{\mathrm{SS}}=-12 \mathrm{~V}$ alınmıştır. Süzgeç için boyutlandırılmış değerler: $\mathrm{C}_{\mathrm{L}}=100 \mu \mathrm{F}, \mathrm{R}_{\mathrm{L}}=10 \Omega \mathrm{R}_{1}=\mathrm{R}_{2}=\mathrm{R}_{3}=1 \mathrm{k} \Omega$ ve $\mathrm{C}=50 \mathrm{nF}$ 'dir. Böylece $\mathrm{L}_{\mathrm{eq}}=60 \mathrm{mH}$ değerinde endüktans elde edilmiştir. Elde edilen endüktans simülatörü kullanılarak alçak geçiren (LP), band geçiren (BP) ve yüksek geçiren (HP) süzgeçler Şekil 6'da gösterilmiştir. Sonuçlar ideal pasif endüktör ile karşılaştırılarak başarım gösterilmiştir. Yüksek geçiren (HP) filtrenin kesim frekansı $185 \mathrm{~Hz}$ 'dir. Alçak geçiren filtrenin kesim frekansı $30 \mathrm{~Hz}$ 'dir. Band geçiren (BP) filtrenin band genişliği yaklaşık olarak $200 \mathrm{~Hz}$ 'dir. 


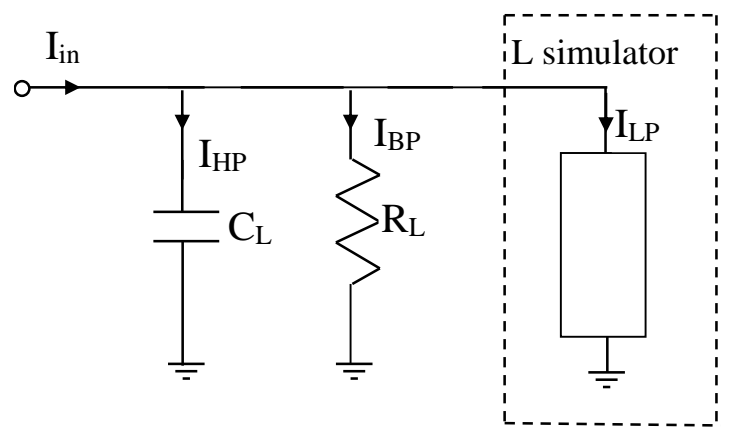

Şekil 5. Önerilen Endüktans Simülatörü ile tasarlanan süzgeç

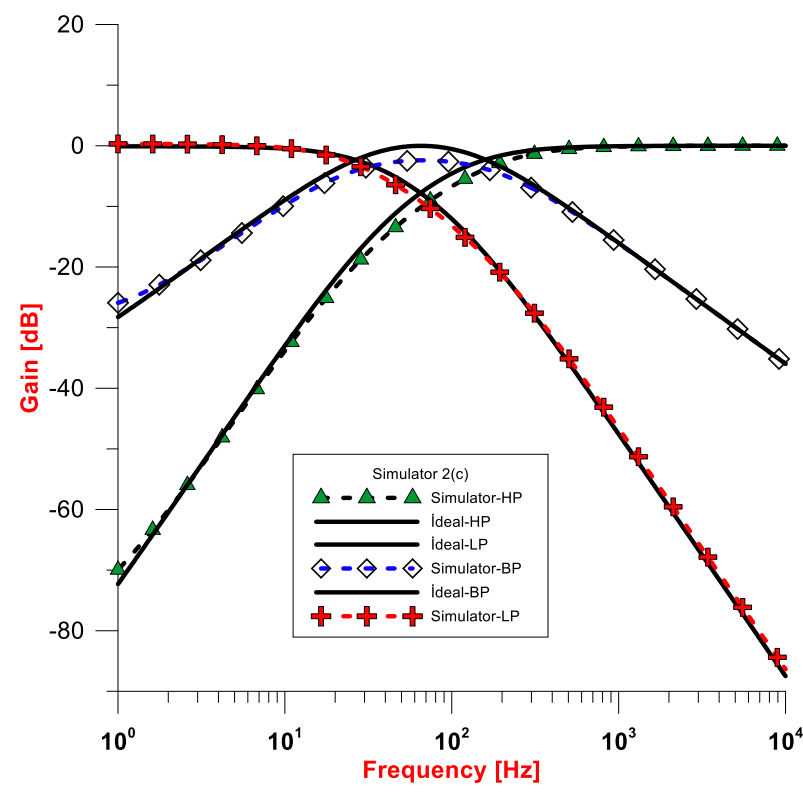

Şekil 6. Önerilen Endüktans Simülatörü ile tasarlanan süzgeçin HP, LP ve BP cevapları

Önerilen endüktans simülatörünün daha yüksek frekanslarda da çalışabildiğini göstermek amacıyla $15 \mathrm{MHz}$ için giriş akımı ve giriş gerilimi arasındaki ilişkinin görünebileceği benzetimler de yapılmıştır.

Şekil 7'de giriş akımının giriş gerilimine göre geride olduğu görülebilir. Ayrıca Şekil 3(c)'deki endüktans simülatörü ile oluşturulan süzgeç devresinin değişen değerlerdeki giriş akımları için Toplam Harmonik Bozulma Yüzdesi Şekil 8'de verilmiştir.

Giriş akımının $13 \mathrm{~mA}$ (tepeden-tepeye) olduğu değerler için Toplam Harmonik Bozulma (THD) yüzdesi \%3.7 olarak bulunmuştur. Toplam Harmonik Bozulmanın kabul edilebilir seviyelerde olduğu söylenebilir.

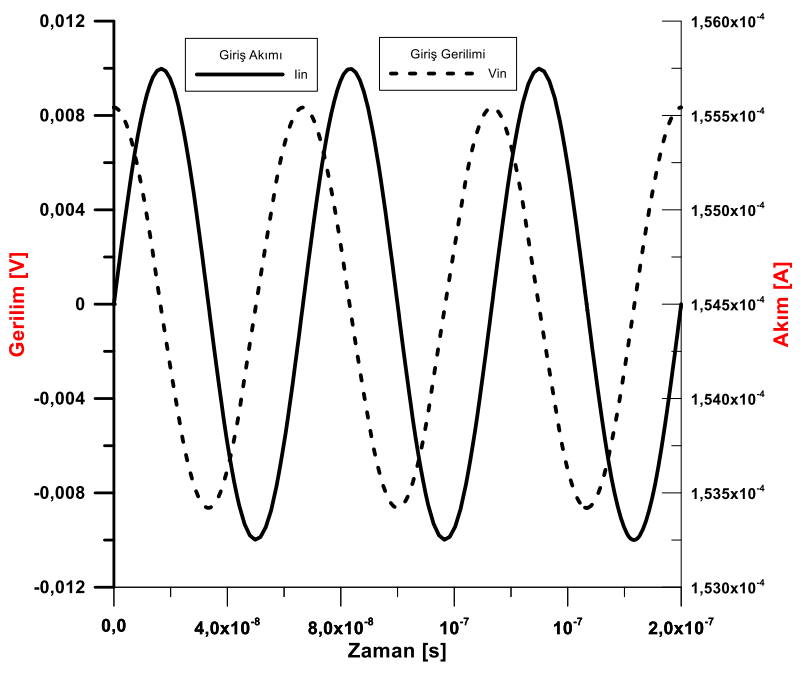

Şekil 7. Önerilen filtrenin giriş akım ve gerilim değişimi

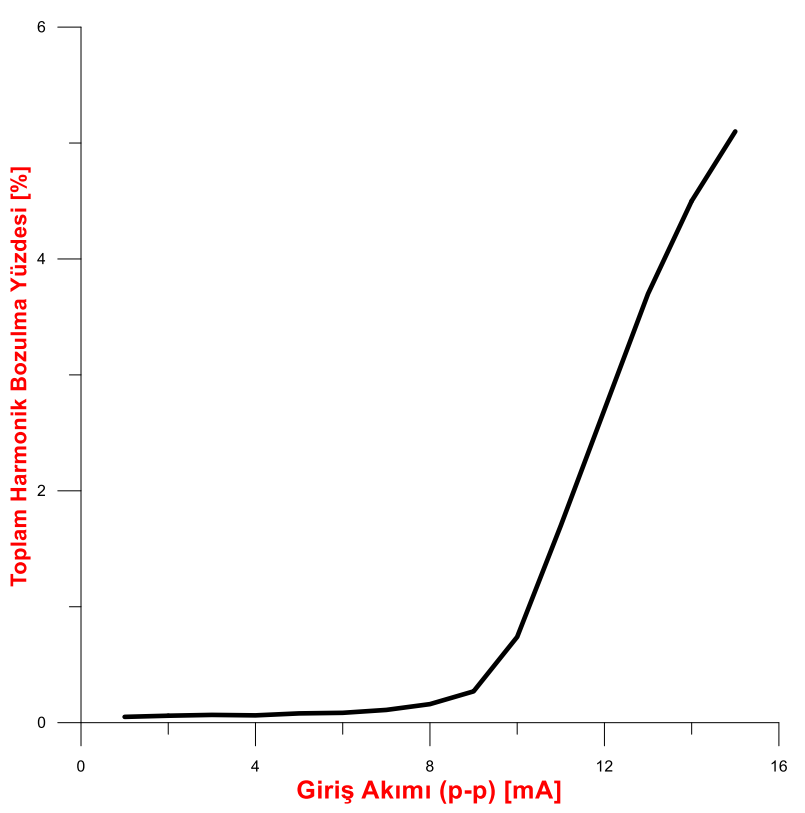

Şekil 8. Önerilen süzgeç için Toplam Harmonik Bozulma Yüzdesi

\section{Sonuc}

$\mathrm{Bu}$ çalışmada, akım geri beslemeli işlemsel kuvvetlendirici kullanılarak topraklanmış üç farklı endüktans simülatörü topolojisi önerilmiștir. Her topoloji sadece bir CFOA aktif devresi içermektedir. Simülasyon sonuçları teorinin doğruluğunu göstermektedir. Devre için hesaplanan Toplam Harmonik Bozulmanın kabul edilebilir seviyelerdedir. Önerilen endüktans simülatörlerinin düşük frekanslarda çalışabilen analog işaret işleme uygulamaları, süzgeç tasarımları, osilatör tasarımları gibi çeşitli uygulamalarda faydalı olacağı düşünülmektedir. 


\section{Kaynaklar}

Abaci, A. ve Yuce, E., 2017. Modified DVCC based quadrature oscillator and lossless grounded inductor simulator using grounded capacitor(s). AEU - International Journal of Electronics and Communications, 76, 86-96.

Abuelma'atti, M.T., 2012. New grounded immittance function simulators using single current feedback operational amplifier. Analog Integrated Circuits and Signal Processing, 71(1), 95-100.

Başak, M.E. ve Kaçar, F., 2018. Lossy/Lossless Grounded Inductance Simulators Using Current Feedback Operational Amplifier (CFOA). Electrica, 18(1), 95-99.

Ferri, G. ve Guerrini, N.C., 2003. Low voltage, low power CMOS current conveyors: NEW YORK, BOSTON, DORDRECHT, LONDON, MOSCOW, Kluwer Academic Publishers.

Ibrahim, M.A., Minaei, S., Yuce, E., Herencsar, N. ve Koton, J., 2011. Lossless grounded inductance simulation using only one modified dual output DDCC, $34^{\text {th }}$ International Conference on Telecommunications and Signal Processing, pp. 261-264.

Ibrahim, M. A., Minaei, S., Yuce, E., Herencsar, N. ve Koton, J., 2012. Lossy/Lossless floating/Grounded inductance simulation using one DDCC. Radioengineering, 21(1), $3-10$.

Kaçar, F. ve Kuntman, H., 2011. CFOA-based lossless and lossy inductance simulators. Radioengineering, 20(3), 627-631.

Kaçar, F., Yeşil, A., Minaei, S. ve Kuntman, H., 2014. Positive/negative lossy/lossless grounded inductance simulators employing single VDCC and only two passive elements. AEU - International Journal of Electronics and Communications, 68(1), 73-78.

Kumar, P. ve Senani, R., 2010. New grounded simulated inductance circuit using a single PFTFN. Analog Integrated Circuits and Signal Processing, 62(1), 105-112.

Nagar, B.C. ve Paul, S.K., 2016. Negative inductance simulator using OTRA, 2016 International Conference on Microelectronics, Computing and Communications (MicroCom), January 2016, Durgapur, India, pp. 2-4.

Paul, A.N. ve Patranabis, D., 1981. Active Simulation of Grounded Inductors Using a Single Current Conveyor. IEEE Transactions on Circuits and Systems, 28(2), 164-165.

Pramanik, A., 2015. Design of operational transresistance amplifier based grounded active inductor and implementation of bandpass filter, $2^{\text {nd }}$ International Conference on Electronics and Communication Systems (ICECS), pp. 842-844.

Sedra, S.A. ve Smith, C.K., 2015. Microelectronics Circuits ( $7^{\text {th }}$ ed.): Oxford, Oxford University Press, 1488 p.

Yesil, A. ve Kacar, F., 2016. VDBA-based lossless and lossy inductance simulators and its filter applications, $24^{\text {th }}$ Signal Processing and Communication Application Conference (SIU), pp. 909-912.

Yeşil, A., Kaçar, F. ve Gürkan, K., 2014. Lossless grounded inductance simulator employing single VDBA and its experimental bandpass filter application. AEU - International Journal of Electronics and Communications, 68(2), 143-150. 